\title{
Physico-Chemical, Organolyptical and Microbiological Characteristics of Substituted Cupcake by Potato Processing Residues
}

\author{
Ibrahim Khalifa, Hassan Barakat*, Hamdy A. El-Mansy, Soliman A. Soliman \\ Department of Food Science, Faculty of Agriculture, Benha University, 13736 Moshtohor, Qaliuobia, Egypt \\ Email: "hassan.barakat@fagr.bu.edu.eg
}

Received 28 December 2014; accepted 7 January 2015; published 13 January 2015

Copyright (C) 2015 by authors and Scientific Research Publishing Inc.

This work is licensed under the Creative Commons Attribution International License (CC BY).

http://creativecommons.org/licenses/by/4.0/

(c) (†) Open Access

\section{Abstract}

Utilization of potato processing residues to produce a low caloric cupcake in present study was targeted. The functional properties of wheat flour (WF 72\%) and dried potato peel varieties [Hermus (PPH) and Russet (PPR)] were carried out. Consequently, WF was partially substituted by both potato peels (PP) at $5 \%-20 \%$ to prepare mixtures for cupcake making. Approximate chemical composition and physical characteristics were determined. Rheological parameters of prepared formulas were assayed using Mixolab. Moreover, total phenolic compounds (TPC) and relative antioxidant activity (AOA) were evaluated. Quality parameters such as thiobarbituric acid (TBA), staling and microbiological attributes during storage were determined. In addition, a sensory evaluation of different substituted cupcake was performed as well. Results indicated that PPR had the highest water absorption capacity (WAC), oil absorption capacity (OAC) and swelling capacity (SC) followed by PPH then WF flours. Indeed, substituted WF with both PP at $5 \%$ and $10 \%$ didn't influence the thermo-mechanical properties including dough time development, stability, viscosity, gluten and starch characteristics drastically. Likewise, this substitution levels didn't affect the organoleptic properties which were confirmed by panelists, cupcake external and cross sections. Substituted WF by 5\% - 10\% PP recorded sensory scores aftermost WF. Mildly, WF cupcake was higher in protein and fat contents than WF-PP cupcakes while lower in crude fiber. The WF-PP cupcakes at different substituted levels recorded lower energy value than WF cupcakes. Arguably, increasing both PP levels increased the TPC and AOA especially for WF-PPR cupcakes. Afterwards, WF-PPR 15\% and $20 \%$ recorded the highest TPC and AOA contents to be $2.32 \mathrm{mg} \mathrm{GAE}$ $\mathrm{g}^{-1} \mathrm{dw}$ and $3.44 \mu \mathrm{mol}$ TE $\mathrm{g}^{-1} \mathrm{dw}$, respectively. No significant difference $(p>0.05)$ was found between WF-PP at 5\% and WF cupcakes in physical and staling properties. WF-PPR cupcakes at different concentrations were lower TBA than WF cupcakes and mostly stable during storage period. It was revealed that substitution levels of $5 \%$ and $10 \%$ with PPH and PPR produced acceptable cupcakes which did not significantly differ from WF cupcakes.

\footnotetext{
${ }^{*}$ Corresponding author.
}

How to cite this paper: Khalifa, I., Barakat, H., El-Mansy, H.A. and Soliman, S.A. (2015) Physico-Chemical, Organolyptical and Microbiological Characteristics of Substituted Cupcake by Potato Processing Residues. Food and Nutrition Sciences, 6, 83-100. http://dx.doi.org/10.4236/fns.2015.61010 
Keywords

Low Caloric Cupcake, Potato Peel Residues, Rheological Properties, Quality, Stability, Revalorization

\section{Introduction}

Cakes are the most consumed bakery product owing to unique products and are always used in festivals as well as in joyous celebrations [1]-[3]. It's increasing worldwide by about $1.5 \%$ per year [4]. It's usually made from soft WF at higher extraction caused deficient in fibers and phytochemicals. Recently, alternative fibers from different sources are available which may provide fibers and phytochemicals as natural components, like fruit, vegetable and their residues [5]. Potato (Solanum tuberosum L.) is one of the main foods in human diets which grow in more than 100 countries. It's the fourth largest crop grown worldwide [6], with world annual production of 367.75 million tons (FAO) [7]. However, peels are the main residues of potato processing which present up to $3 \%$ - 5\% causing many environmental problems [8]. PP is a good source of natural antioxidants [9] [10], phenolic compounds [8] [11] [12] especially purple potato variety "Russet" [13]-[16] and fibers [17].

Many epidemiological studies assert that fibers consumption helps to reduce obesity, some cancer kinds and cardiovascular diseases [18]-[21]. Therefore, the fibers consumption recommended to be up to 20 - $35 \mathrm{~g}$ daily [22]. Newly, some researches were mentioned that food residues could be incorporated into cake making such as carrot leafs [23], watermelon rinds and sharlyn melon peels powders [24], potato peels [17] [25], flaxseeds [26] and apple pomace [27] [28]. Indeed, incorporating the PP could increase its added-value, decrease the cupcake total manufacturing coast and provide phytochemicals, antioxidants into the human diets.

Therefore, the aim of this study was to study the applicability of WF $72 \%$ substitution by both dried PP powder in cake making to produce low caloric cupcake. To achieve this aim, functional properties of WF and PP were determined. Consequently, approximate chemical composition, physical characteristics, rheological parameters of prepared mixtures were investigated. Moreover, TPC and AOA were evaluated. Quality parameters and sensory evaluation of different substituted cupcake were performed as well.

\section{Material and Methods}

\subsection{Chemicals and Media}

1,1-diphenyl-2 picrylhydrazyl radical (DPPH ${ }^{\bullet}$ ) and 6-hydroxy-2,5,7,8-tetramethylchroman carboxylic acid (Trolox) were obtained from Sigma Aldrich, Germany. Folin-Ciocalteu reagent, Fluka Co., France, Gallic acid, Serva, fine Biochemical, New York. Tryptic glucose yeast agar (TGYA, code No. 4021452), Rose Bengal agar (RBA, Biolife code No. 401992) and Violet red bile agar (VRBA, code No. 402185), were obtained from Biolife, Italy.

\subsection{Raw and Baking Materials}

1) Both PP (PPH and PPR) from the crop of session 2012 were obtained from Egypt Foods Co., Industrial Zoon, Quesna City, Egypt.

2) Soft WF (72\% extraction) were obtained from Cairo South Co. of Milling, Cairo, Egypt.

3) Baking ingredients such as sugar (sucrose; a commercial grade), salt, skimmed milk powder, shortening, fresh whole egg, baking powder and vanilla were obtained from local supermarket, Tukh City, Qaliuobia, Egypt.

\subsection{Potato Processing Residues Preparation}

The obtained PP residues in fresh status were transferred immediately to the analytical lab. Both PP were dried by oven dryer (Tit Axon S.R.L via Canova, Italy) at $40^{\circ} \mathrm{C}-50^{\circ} \mathrm{C}$ gradually for $12 \mathrm{~h}$. Subsequently, the dried peels were milled by grinder (Severin, Type 3871, Germany) and passed through a 60 mesh sieve to obtain fine homogenous powder. The PP meals were immediately packed in dark glass jars then kept at $-18^{\circ} \mathrm{C} \pm 1^{\circ} \mathrm{C}$ 
until use.

\subsection{Processing of Cupcakes Formulas}

All formulas of substituted WF at different substitution levels by both PP were summarized in Table 1 . The processing method of cupcake was taken typically according to A.A.C.C. [29] in steps sequence as: The shortening was melted thoroughly; sugar and salt were added then mixed vigorously. The whole egg was mixed with vanillia and whipped until got puff and smooth like-cream texture. Additionally, substituted WF with both PP (PPH and PPR) at 5\%, 10\%, 15\% and 20\% were mixed individually with 2.15\% baking powder and $4.30 \%$ skimmed milk powder then added gradually to whipped egg mixture. This mixture was mixed gently until got homogenous dough using Hand mixer (MK-H4-W, Panasonic Co, Malaysia). After getting appropriate texture the dough was poured into paper cups and backed at $180^{\circ} \mathrm{C} \pm 5^{\circ} \mathrm{C}$ for $30-35 \mathrm{~min}$. The baked cupcakes were cooled down at room temperature, then packed into aluminum foil bags then stored at room temperature for 8 days. Samples were taken during the storage periods at 0, 5, 8 day intervals for analysis. Finally, the photos for external and cross-sections were taken directly after the end of baking using an Olympus digital camera 8 MP model FS-32.

\subsection{Analytical Methods}

\subsubsection{Determination of Functional Properties of Wheat Flour and Both Potato Residues}

Both PP and WF were subjected to functional properties analysis. WAC and OAC were determined according to the modified method by Heywood et al. [30]. Fifty gram sample from each prepared PP or WF were dispersed in $285 \mathrm{ml}$ distilled water or oil in a $500 \mathrm{ml}$ centrifuge bottle. Bottles were agitated for $10 \mathrm{~min}$ then centrifuged at $4000 \times \mathrm{g}$ for $30 \mathrm{~min}$. After decanting the supernatant, each bottle was weighed and WAC or OAC was calculated as ( $\mathrm{g}$ of water or oil $\mathrm{g}^{-1}$ flour $\mathrm{dw}$ ). Also, SC was measured using the bed volume technique as described by Kuniak and Marchessault [31]. Sample about 0.5 - $1.0 \mathrm{~g}$ was weighed into a $15 \mathrm{ml}$ falcon tube, $10 \mathrm{ml}$ of phosphate buffer were added and the suspension had been stirred. After equilibration for $16 \mathrm{~h}$, the volume was recorded and expressed as $\mathrm{ml} \cdot \mathrm{g}^{-1} \mathrm{dw}$.

\subsubsection{Approximate Chemical Composition}

WF cupcakes and different substituted PP cupcakes were subjected immediately to chemical composition analysis [moisture, ash, crude fat, crude fiber and crude protein], according to A.A.C.C. [32]. The available carbohydrates content was calculated by difference according to FAO [33]. To calculate the food energy value, the main components were converted using conversion factors as $\left[16.75 \mathrm{~kJ}^{-1}\right.$ for (proteins and available carbohydrates), $37.68 \mathrm{~kJ} \cdot \mathrm{g}^{-1}$ for (fats) and $8.37 \mathrm{~kJ} \cdot \mathrm{g}^{-1}$ for (fiber)] according to FAO [33].

\subsubsection{Physical Characteristics}

The normal weight (g) of baked cupcakes was determined individually within one hour after baking and the

Table 1. Raw ingredients of processed cupcake.

\begin{tabular}{cc} 
Ingredients & Weight (g) \\
\hline Soft wheat flour (72\% extraction) & 250.0 \\
Sugar & 125.0 \\
Salt & 3.50 \\
Skimmed milk powder & 25.0 \\
Shortening & 53.50 \\
Fresh whole egg & 110.0 \\
Baking powder & 12.50 \\
Vanillia & 2.0 \\
\hline
\end{tabular}


average was calculated. The volume $\left(\mathrm{cm}^{3}\right)$ of different substituted cupcakes was determined by rape seeds displacement method according to A.A.C.C. [32]. Also, the specific weight was calculated for different substituted cupcake.

\subsubsection{Total Phenolic Compounds and Antioxidant Activity}

1) Total phenolic compounds

The TPC of methanolic extracts from different cupcake formulas was determined calorimetrically using the Folin-Ciocalteau method according to Sudha et al. [28]. One g of defatted sample [after refluxing with chloroform and petroleum ether, $(1: 1 \mathrm{v} / \mathrm{v})$ followed by drying] was mixed with $10 \mathrm{ml}$ methanol, then stirred and centrifuged at $2000 \times \mathrm{g}$ for $15 \mathrm{~min}$ to obtain clear methanolic extract. Appropriate extracts dilutions were reacted with Folin-Ciocalteau reagent then $2 \mathrm{ml}$ of $10 \% \mathrm{Na}_{2} \mathrm{CO}_{3}$ were added. After $1 \mathrm{~h}$ at ambient temperature, the absorbance was measured at $765 \mathrm{~nm}$ and The TPC was expressed as milligram gallic acid equivalents per gram sample (mg GAE g${ }^{-1} \mathrm{dw}$ ) using this equation:

$$
Y=0.0201 x+0.0538 \quad\left(R^{2}=0.99\right)
$$

where: $Y$ is the concentration and $x$ is the absorbance.

2) Determination of antioxidant activity

The antioxidant activity (AOA) of different substituted cupcake was determined using $\mathrm{DPPH}^{\bullet}$ assay according to Lee et al. [34] with minor modification. A $0.1 \mathrm{ml}$ for methanolic extract for each sample was vortexed for $30 \mathrm{~s}$ with $3.9 \mathrm{ml}$ of $\mathrm{DPPH}^{\bullet}$ solution and left to react for $30 \mathrm{~min}$, afterword the absorbance at $515 \mathrm{~nm}$ was recorded and expressed as micromoles of trolox equivalents (TE) per gram of dry weight $\left(\mu \mathrm{mol} \mathrm{TE} \mathrm{g}{ }^{-1} \mathrm{dw}\right.$ ).

\subsection{Determination of Some Quality Parameters for Different Substituted Cupcakes during Storage}

Determination of TBA and Staling

The amount of lipid oxidation in different substituted cupcakes was determined by the 2-thiobarbituric acid (TBA) method according to A.O.C.S. [35]. However the staling of different baked cupcakes containing different levels of PP meal was measured by alkaline water retention capacity (AWRC) according to A.A.C.C. [32].

\subsection{Rheological Parameters}

The effect of both PP meal substitution at 5\%, 10\%, 15\% and 20\% on WF thermo-mechanical and rheological parameters were determined using Mixolab apparatus (20 AV MARCELLIN BERTHELOT, CHOPIAN, France) according to Dubat [36].

\subsection{Organoleptic Properties}

The organoleptic properties of different substituted cupcakes was carried out in a standardized test room in morning sessions (11:00-13:00 h) by properly 28 well trained panelists according to A.A.C.C. [32]. They were selected if their individual scores in 10 different tests showed a reproducibility of $90 \%$. Mineral water was used by the panelists to rinse the mouth between samples. Cupcake samples were left to cool at room temperature for $1 \mathrm{~h}$ after baking, then cut with a sharp knife and subjected to panel test. The score was distributed as: 40: crumb cells (10: uniformity, 10: cells size, 10: walls thickness and 10: color), 30: texture (10: moistness, 10: tenderness and 10: softness), 10: crust color, 10: odor, 10: taste, and 100: overall acceptability. Results were expressed as mean \pm SD.

\subsection{Microbiological Attributes}

Total bacteria count (TBC), coliform group (CG) and yeast \& molds (Y \& M) were evaluated periodically in different substituted cupcakes during different storage periods. Under sterile conditions, serial dilutions were prepared and inoculated then TGYA, RBA and VRBA were poured. All plates were incubated at $37^{\circ} \mathrm{C}$ for $48 \mathrm{~h}$ for TBC and CG while at $28^{\circ} \mathrm{C}$ for 3 - 5 days for $\mathrm{Y} \& \mathrm{M}$. All microbiological examinations were performed in triplicates. 


\subsection{Statistical Analysis}

The statistical analysis was carried out using SPSS program (ver. 19) with multi-function utility regarding to the experimental design under significance level of 0.05 for the whole results and multiple comparisons were carried out applying LSD with Duncan according to Steel et al. [37].

\section{Results and Discussion}

\subsection{Functional Properties of Wheat Flour and Potato Peels Residue}

The functional properties including WAC, OAC and SC of WF 72\% and both PP residue were determined, data were tabulated in Table 2. The obtained data observed that PPR and PPH had higher WAC, OAC and SC than WF flours significantly. However, no significant difference $(p>0.05)$ was found between PPH and PPR in WAC, while significant difference $(p<0.05)$ was observed between them in OAC and SC. These results are in agreements with some publications [38] [39]. Recently, Dhingra et al. [17] remarked that PP is considered as a good source of dietary fibers which may be efficiently usable in bakery products.

\subsection{Effect of Wheat Flour Substitution by Potato Peels Residue on Rheological and Thermo-Mechanical Parameters Determined by Mixolab}

The effect of WF substitution by PP residue on protein and starch properties was monitored using Mixolab apparatus. Mixolab is a new instrument that can monitor dough rheological properties during mixing under controlled conditions. It is allowable to perform continuous rheological measurements of dough into a simulation of thermal-processing. In Mixolab curve, there are five parameters should be considered; $\left(\mathrm{C}_{1}\right)$ : maximum torque of the initial mixing stage, $\left(\mathrm{C}_{2}\right)$ : protein weakening, $\left(\mathrm{C}_{3}\right)$ : starch gelatinization, $\left(\mathrm{C}_{4}\right)$ : physical breakdown of gelatinized starch granules, and $\left(\mathrm{C}_{5}\right)$ : starch retrogradation as explained by Kahraman et al. [40].

The effect of WF substitution by PP residue on the absorption, mixing, gluten, viscosity, amylase and retrogradation were investigated, results were presented in Figure 1(a) and Figure 1(b). Partially substituted WF by PPH and PPR at 5\% - 20\% altered the dough properties as recorded in their Mixolab profiles. The absorption was increased rapidly with increasing the PPH and PPR levels. Gluten, amylase and retrogradation were decreased in substituted WF with more than $10 \%$ PP. However, the viscosity wasn't changed drastically (Figure 1(a) and Figure 1(b)). The WF-PPH 20\% recorded the highest absorption, while the WF was lower absorption than all substituted WF. Generally, both PP caused increasing in absorption, owing to their contents of starch and fibers. Mildly, the viscosity and amylase parameters weren't affected significantly. Thereby, the stable viscosity formulas had harder texture which may be useful to avoid mechanical damage of products during transport and handling [41]. Particularly, both PP reduced the gluten and retrogradation characteristics when compared with WF. These phenomena may owe its chemical composition exhibit low protein contents.

Stability and water absorption are one of the most important properties. The effects of PP residue incorporated into WF on those properties were tabulated in Table 3. Not only WF had the high stability but also the WF-PPR $10 \%$ had higher stability than all substituted formulas to be 11.17 and $10.97 \mathrm{~min}$, respectively. Conversely, the WF-PPH and PPR 20\% recorded lower stability than all formula to be $10.47 \%$ and $10.57 \%$, respectively; this may be due to their higher fibers content. The higher fibers content caused decreasing in dough stability as mentioned before by Torbica et al. [42].

Table 2. Functional properties of wheat flour and potato peels residues.

\begin{tabular}{cccc}
\hline & & Functional properties & \\
\cline { 2 - 4 } Item & WAC [g of water g $\left.{ }^{-1} \mathrm{dw}\right]$ & OAC [g of oil g $\left.{ }^{-1} \mathrm{dw}\right]$ & SC $\left[\mathrm{ml} \cdot \mathrm{g}^{-1} \mathrm{dw}\right]$ \\
\hline Potato peel "Hermus" (PPH) & $5.79 \pm 0.07^{\mathrm{b}}$ & $2.82 \pm 0.13^{\mathrm{b}}$ & $7.00 \pm 0.20^{\mathrm{b}}$ \\
Potato peel "Russet” (PPR) & $5.98 \pm 0.15^{\mathrm{b}}$ & $3.25 \pm 0.09^{\mathrm{c}}$ & $7.77 \pm 0.25^{\mathrm{c}}$ \\
Wheat flour (WF) & $3.37 \pm 0.06^{\mathrm{a}}$ & $1.82 \pm 0.09^{\mathrm{a}}$ & $4.60 \pm 0.17^{\mathrm{a}}$ \\
\hline
\end{tabular}

a,b,c: Means with the same letter in the same column are not significantly different ( $p>0.05)$. ${ }^{*}$ Wheat flour contained: 6.30, 10.33, 10.12, 110.76 and $850.09 \mathrm{~g} \cdot \mathrm{kg}^{-1} \mathrm{dw}$ for ash, fat, fibers, protein and available carbohydrates, respectively as well as $110.50 \mathrm{~g} \cdot \mathrm{kg}^{-1}$ moisture. 
Table 3. Water absorption and stability of wheat flour and substituted WF by potato residues.

\begin{tabular}{|c|c|c|c|}
\hline \multirow{2}{*}{ Flour blends* } & \multirow{2}{*}{ Substitution level (\%) } & \multicolumn{2}{|c|}{ Mixolab parameters } \\
\hline & & Water absorption (\% b14) & Stability (min) \\
\hline Wheat flour & 0 & 55.00 & 11.17 \\
\hline \multirow{4}{*}{ WF-PPH } & 5 & 57.60 & 10.78 \\
\hline & 10 & 61.30 & 10.55 \\
\hline & 15 & 63.20 & 10.82 \\
\hline & 20 & 67.80 & 10.47 \\
\hline \multirow{4}{*}{ WF-PPR } & 5 & 56.80 & 10.58 \\
\hline & 10 & 58.60 & 10.97 \\
\hline & 15 & 61.40 & 10.60 \\
\hline & 20 & 61.30 & 10.57 \\
\hline
\end{tabular}

*These blends were composed of wheat flour substituted by PP residues at different concentration. ${ }^{* *}$ These data was basically calculated on $14 \%$ moisture content in WF.

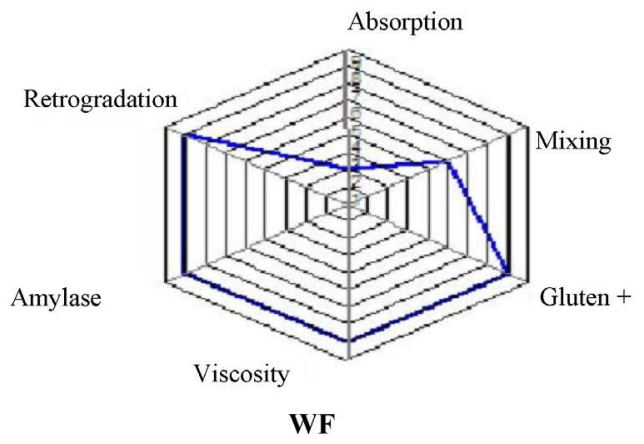

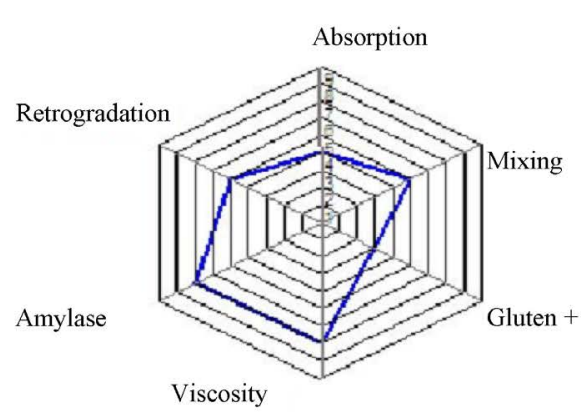

WF-PPH 5\%

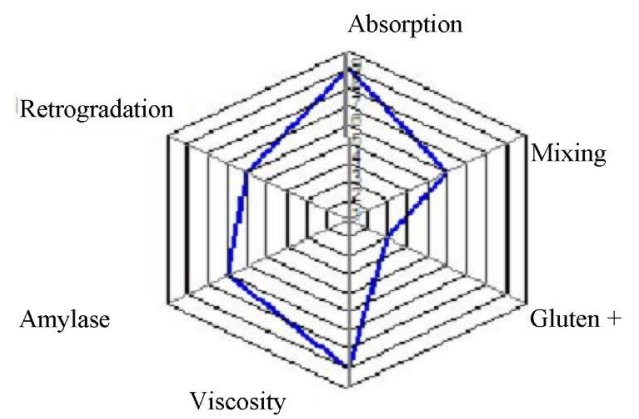

WF- PPH 15\%

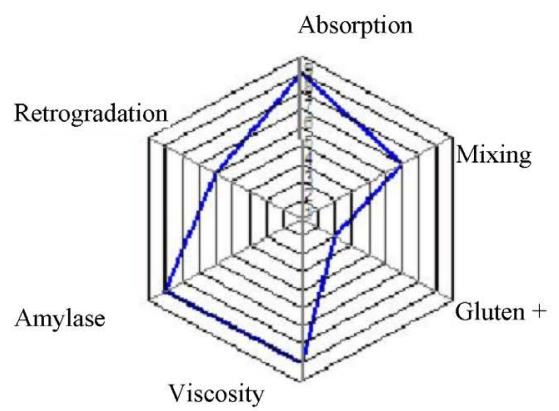

WF-PPH $10 \%$

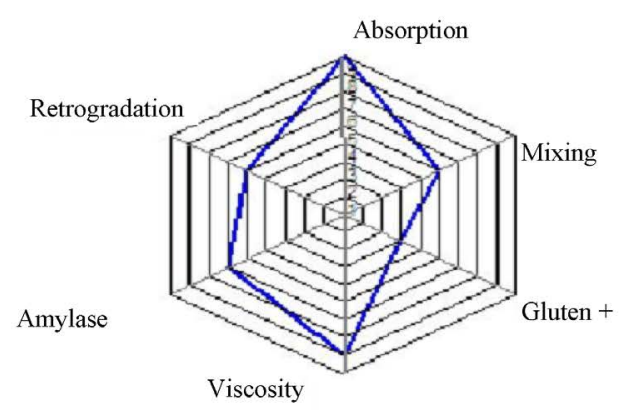

WF- PPH 20\%

(a) 


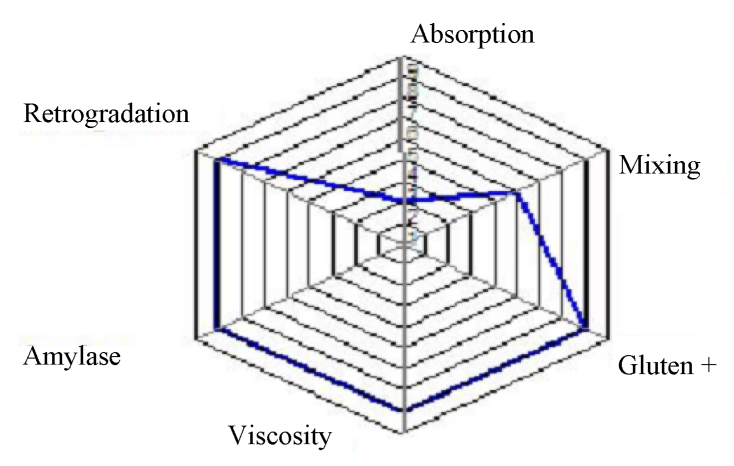

WF

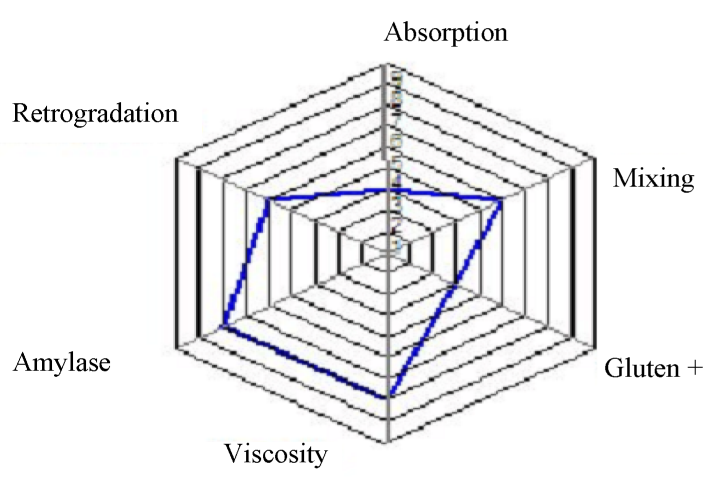

WF-PPR 5\%

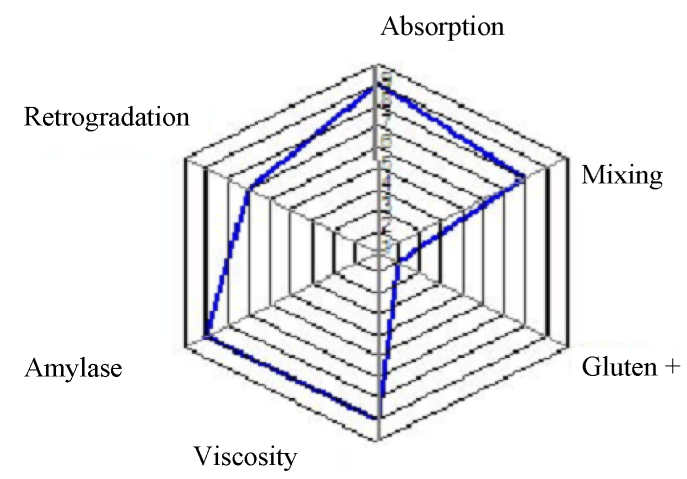

WF- PPR 15\%

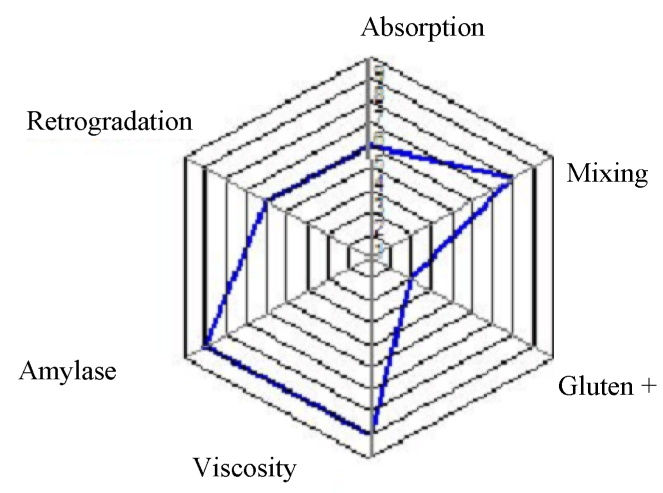

WF- PPR 10\%

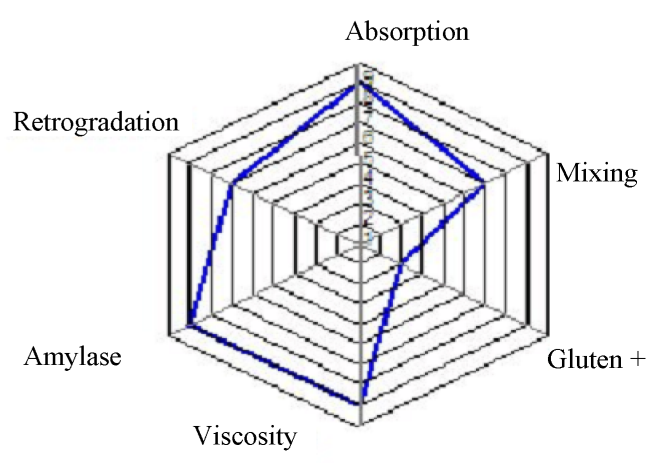

WF- PPR 20\%

(b)

Figure 1. (a) A Mixolab typical target profile of wheat flour 72\% (WF) and substituted WF by different substitution levels of PPH at 5\%, 10\%, 15\%, and 20\% (w:w); (b) A Mixolab typical target profile of wheat flour $72 \%$ (WF) and substituted WF by different substitution levels of PPR at 5\%,10\%,15\%, and 20\% (w:w).

Conversely, substitution of WF with PPH recorded higher water absorption than PPR. For instance, the WF-PPH 20\% recorded the highest water absorption to be $67.80 \%$. As shown in Figure 2, it seems to be that there are differences in the thermo-mechanical and rheological parameters of substituted WF at arranges of $30^{\circ} \mathrm{C}$ depend on residue type and substitution level. Generally, adding 5\% of both PP wasn't affected the dough time development. Also, the increasing of PP levels especially PPR resulted in longer dough development time due to their contents of starch to be 8.13 and $\min 8.15$ for WF-PPR $15 \%$ and $20 \%$, respectively. As for $\mathrm{C}_{2}$, negligible difference was observed among all formulas. Thus, the WF-PPR 15\% scored the lowest torque in this period to be $0.40 \mathrm{Nm}$. In contrary, WF recorded the highest torque compared with other formulas to be $0.56 \mathrm{Nm}$. This 
may reflects the strength and weakening of protein for each formula including WF [42] [43]. For $\mathrm{C}_{3}$, the WF-PPR $5 \%$ was the lowest torque in $\mathrm{C}_{4}$ and $\mathrm{C}_{5}$ periods, but the WF was the highest torque in $\mathrm{C}_{4}$ and $\mathrm{C}_{5}$, respectively. This may be due to the properties of starch during heating and cooling. Also, in these periods the variation in time among formulas was negligible. Until now and to the best of our knowledge, no work about the thermo-mechanical and rheological parameters of WF incorporated PP were found. Finally, the results are in agreements with Kahraman et al. [40] who reported that, making a good cake flour should have low in $\mathrm{C}_{3}, \mathrm{C}_{4}$ and $C_{5}$ values which indicate the importance of the starch phase of used flour in making of cake.

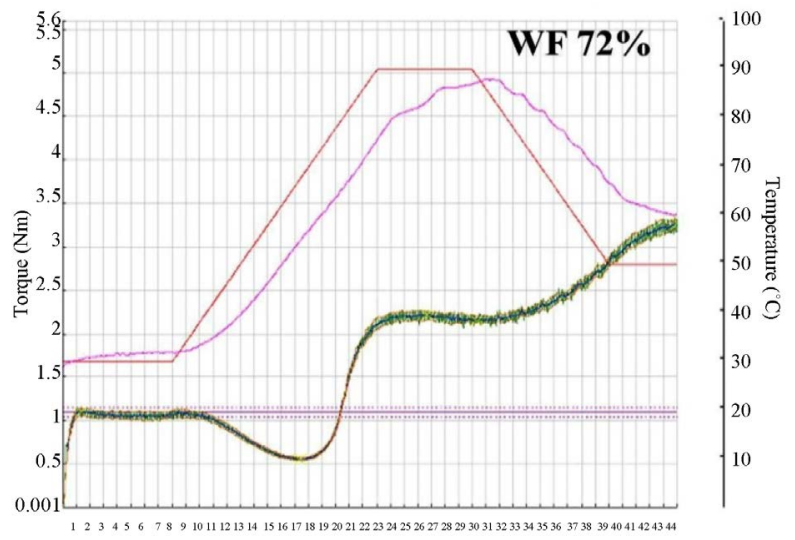

Time (min)

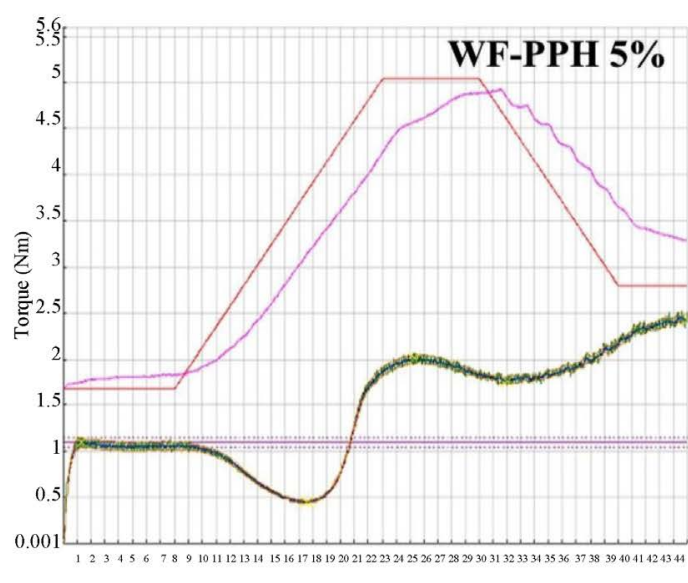

Time (min)

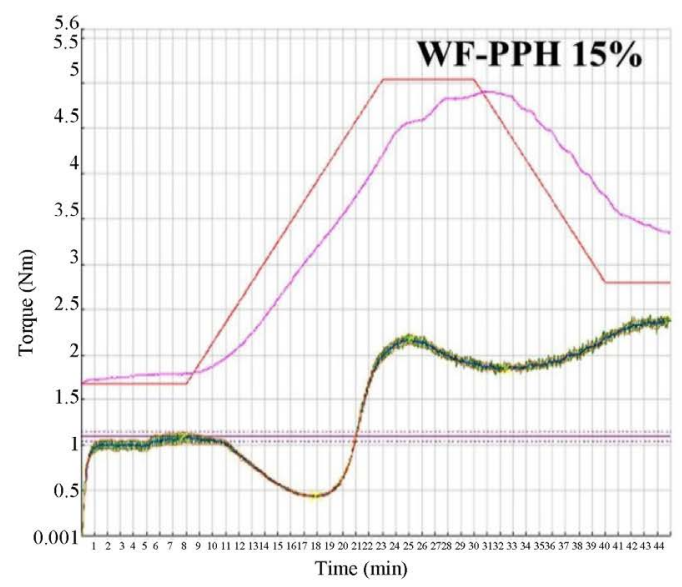

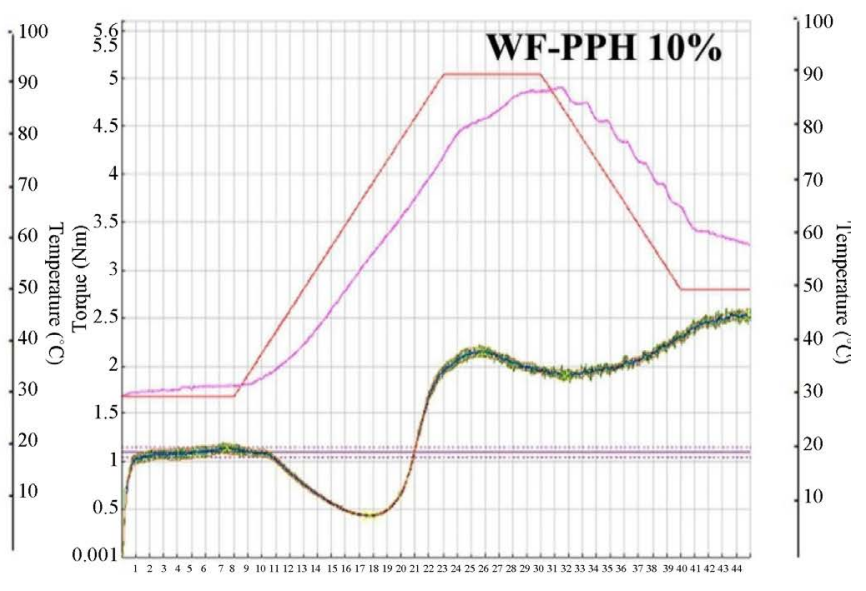

Time (min)
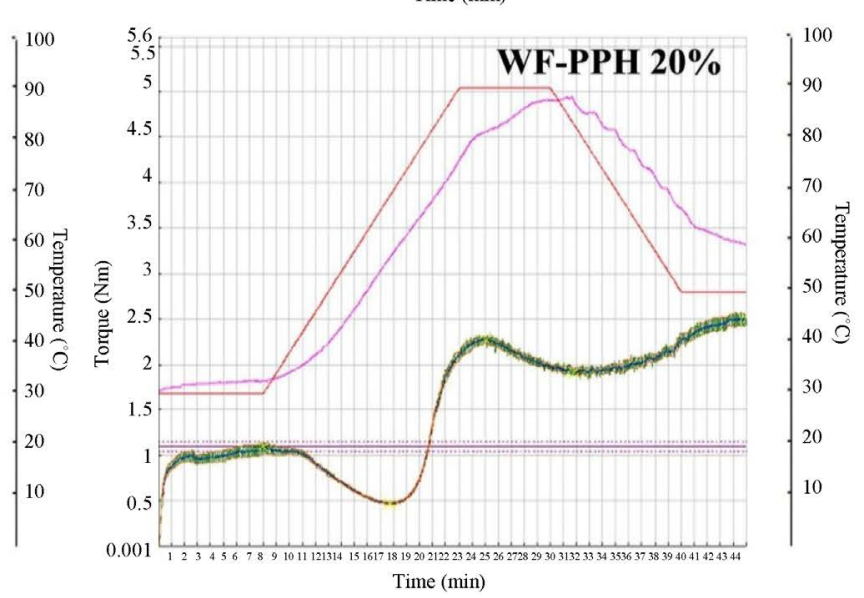

(a) 


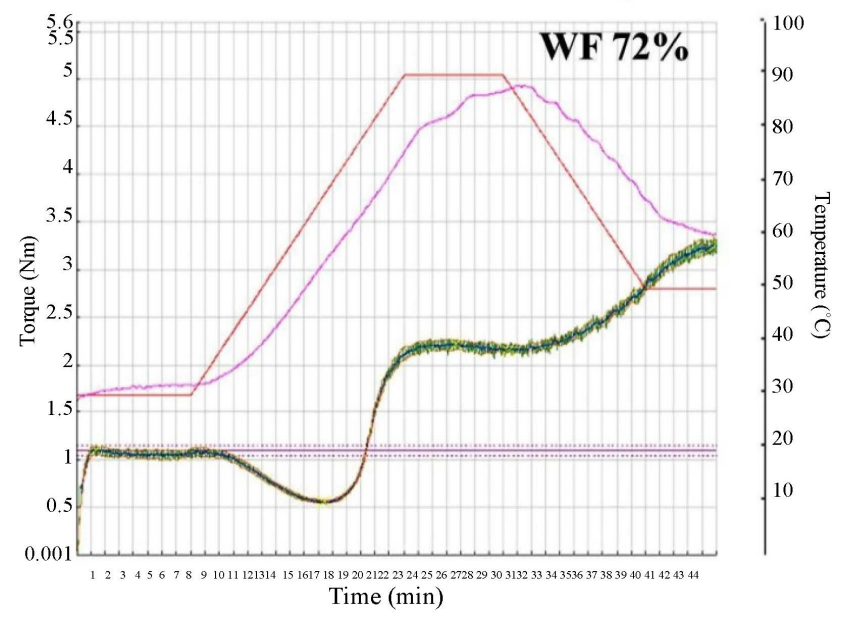

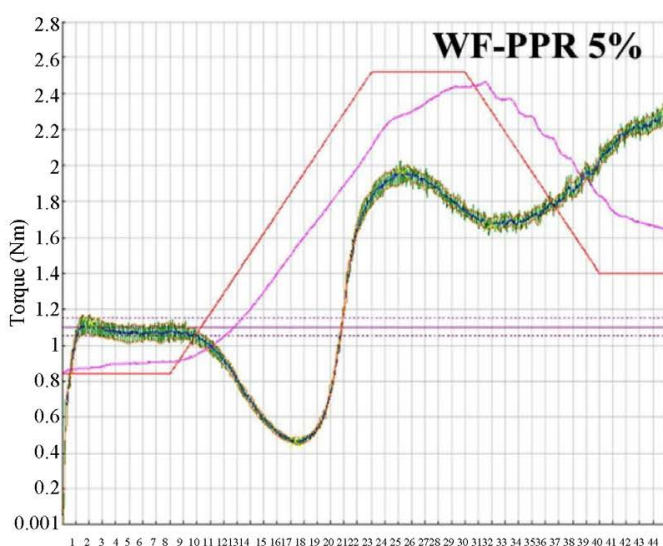

Time (min)

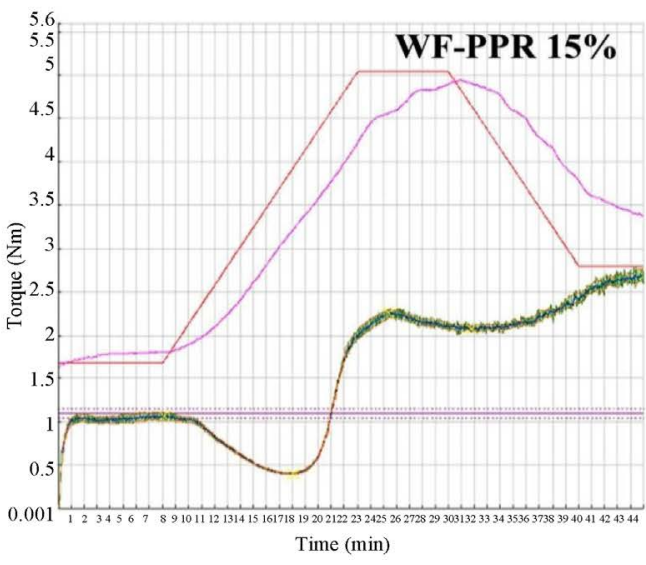

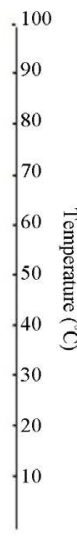

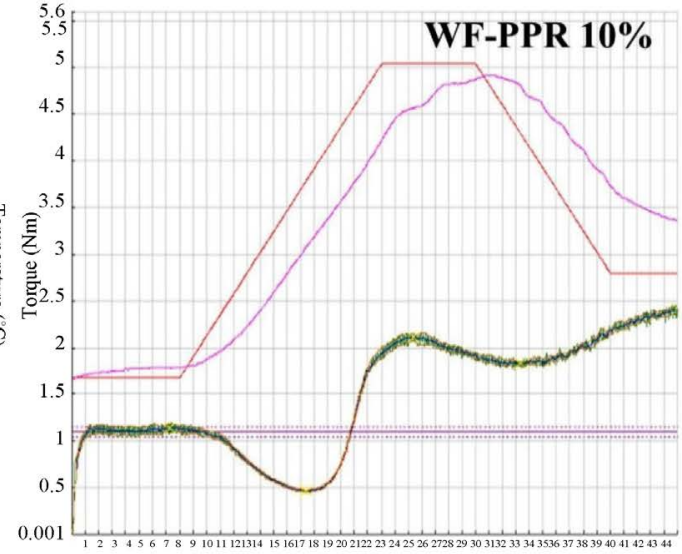

Time (min)
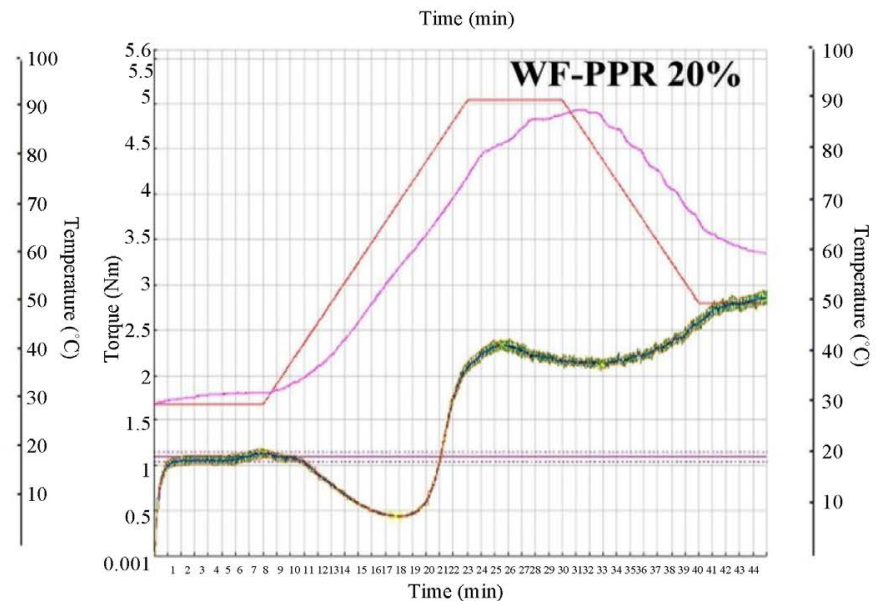

(b)

Figure 2. (a) Thermo-mechanical and rheological parameters of substituted wheat flour (72\%) with different substitution levels of PPH at 5\%,10\%, 15\%, and 20\% (w:w); (b) Thermo-mechanical and rheological parameters of substituted wheat flour (72\%) with different substitution levels of PPR at 5\%, 10\%, 15\%, and 20\% (w:w).

\subsection{Organoleptic Properties of Different Substituted Cupcakes with Potato Peels Residue}

The effect of substituted WF by PP residue used in making of cupcake on organoleptic properties were studied, data was presented in Table 4. Twenty eight trained panelists were asked to judge cupcake parameters include texture properties (moistness, tenderness and softness), crumb cells (uniformity, size, thickness and color), 


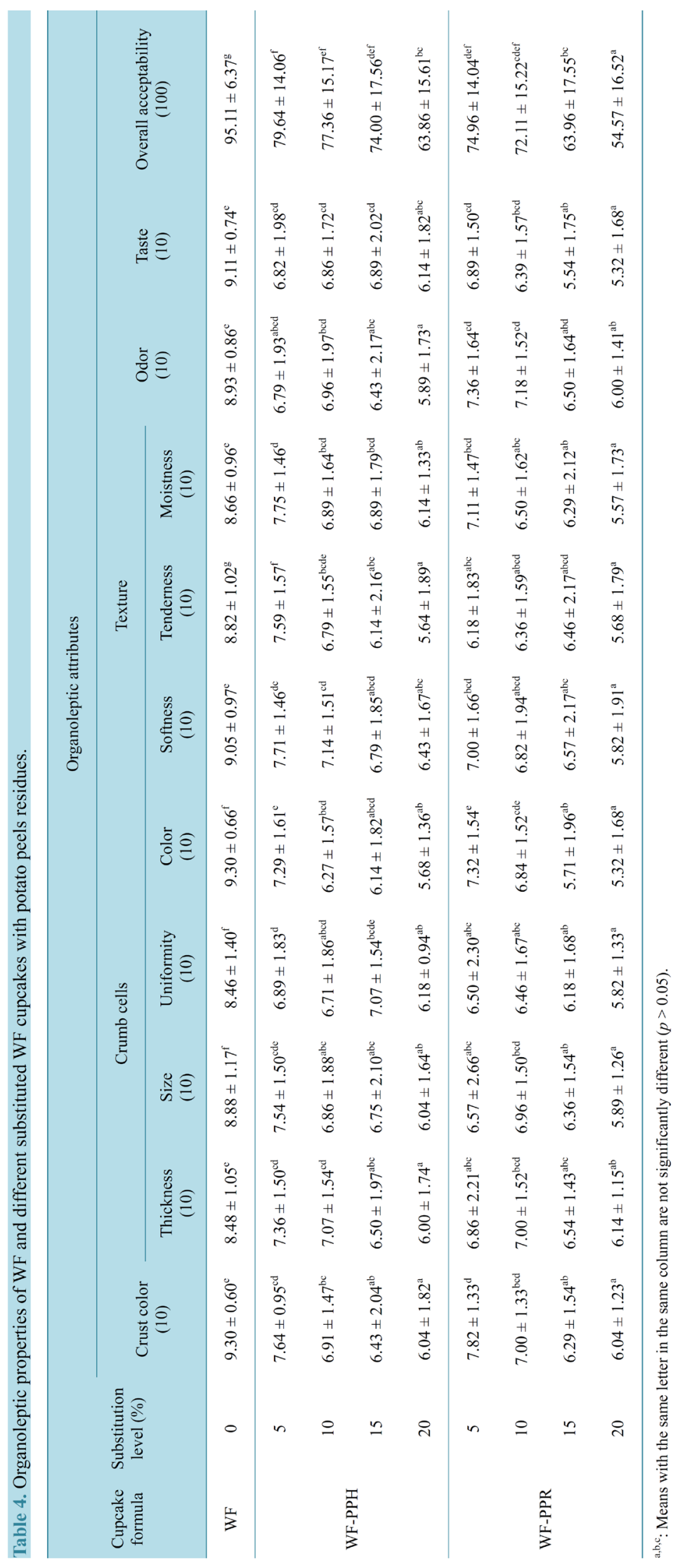


(crumb color, odor and taste) and overall acceptability as well. Surely, significant differences $(p<0.05)$ were observed between cupcake formulas and WF cupcakes in all organoleptic characteristics. Increasing of PP affected dramatically the organoleptic properties. For example, the higher and the lower overall acceptability was observed for WF and WF-PPR 20\% cupcakes to be $95.11 \%$ and $54.47 \%$, respectively. Also, the lowest concentration of PP cupcakes was aftermost WF cupcakes. Generally, WF-PPR 5\% cupcake was followed the WF cupcake in crust color scores, whereas the WF-PPH and WF-PPR 20\% cupcakes recorded lower crust color than all formulas. Regarding the crumb cells properties, the WF-PPR 20\% cupcake recorded the lowest formula in color, uniformity and size, while the WF-PPH 20\% cupcake was the lowest formula in thickness property. Not only WF-PPH 5\% cupcake was similar to WF cupcake but also significant differences $(p<0.05)$ in texture properties were noticed between WF cupcake and different cupcakes formulas. Likewise, WF-PPR $20 \%$ cupcake was the lowest formula in softness, moistness and taste. In contrast, the WF-PPH 20\% cupcake was the lowest formula in tenderness and odor characteristics. Surly, data in Figure 3 illustrated that the addition of PP residues at $5 \%$ or $10 \%$ wasn't influenced the organoleptic properties as remarked in external and cross sections of cupcake when compared with WF cupcake. The increasing of PP residue leads to increase the dark color and coarser textures. However, these results are agreed and supported by previous results of Al-Sayed and Ahmed [24].

\subsection{Approximate Chemical Composition of Different Substituted Cupcakes with Potato Peels Residue}

The proximate chemical composition of baked cupcakes from WF and substituted WF by PP residue at different concentration was determined; data was tabulated in Table 5. Mildly, adding of PP residue increased the moisture and ash contents. WF-PPR 20\% cupcake recorded the highest moisture and ash contents to be 30.88 and $2.43 \%$, respectively. WF cupcake was higher in protein content than other cupcakes to be $8.97 \%$. Whereas, no significant difference $(p>0.05)$ had been found between all substituted and WF cupcake. Addition of both PP residues especially with high concentration purposed to increase the crude fibers. Indeed, the WF cupcake was lower in crude fibers than both PP cupcakes. No significant difference $(p>0.05)$ was found between both PP cupcakes at 5\% and 10\% substitution level and WF cupcake. The incorporated PP into cupcake at different concentrations recorded lower energy value than WF cupcake. To emphasize that, the WF-PPR 20\% cupcake was the lowest energy value to be $1257.90 \mathrm{~kJ} \cdot \mathrm{g}^{-1}$. These results are in agreement with some previous studies [4] [24] [44] [45].

Table 5. A proximate chemical composition of WF and different substituted WF cupcakes with potato peels residues.

\begin{tabular}{|c|c|c|c|c|c|c|c|c|}
\hline \multirow{2}{*}{$\begin{array}{l}\text { Cupcake } \\
\text { formula }^{* *}\end{array}$} & \multirow{2}{*}{$\begin{array}{l}\text { Substitution } \\
\text { level (\%) }\end{array}$} & \multicolumn{7}{|c|}{ Compounds } \\
\hline & & Moisture ${ }^{*}$ & $\operatorname{Ash}^{\bullet^{*}}$ & Crud protein"* & Crud fat ${ }^{\mathbf{}^{*}}$ & Crud fiber ${ }^{\mathbf{*}^{*}}$ & $\begin{array}{c}\text { Available } \\
\text { carbohydrate }^{* *}\end{array}$ & $\begin{array}{l}\text { Energy value } \\
\qquad\left(\mathrm{kJ} \cdot \mathrm{g}^{-1}\right)^{\mathbf{n}}\end{array}$ \\
\hline \multirow[t]{2}{*}{ WF } & 0 & $26.26 \pm 1.10^{\mathrm{a}}$ & $1.45 \pm 0.24^{\mathrm{a}}$ & $8.97 \pm 0.17^{\mathrm{d}}$ & $9.79 \pm 1.84^{\mathrm{abc}}$ & $0.70 \pm 0.25^{\mathrm{a}}$ & $79.80 \pm 2.06^{\mathrm{a}}$ & $1364.90 \pm 5.29^{\mathrm{de}}$ \\
\hline & 5 & $26.90 \pm 0.44^{\mathrm{ab}}$ & $1.72 \pm 0.15^{\mathrm{abc}}$ & $6.90 \pm 0.93^{\mathrm{abcd}}$ & $8.45 \pm 0.67^{\mathrm{ab}}$ & $0.86 \pm 0.25^{\mathrm{ab}}$ & $82.93 \pm 1.41 d^{b}$ & $1334.66 \pm 7.06^{\text {cde }}$ \\
\hline \multirow{3}{*}{ WF-PPH } & 10 & $29.28 \pm 1.97^{\text {cdef }}$ & $1.83 \pm 0.07^{\mathrm{bc}}$ & $5.73 \pm 1.30^{\mathrm{a}}$ & $8.74 \pm 2.10^{\mathrm{ab}}$ & $1.29 \pm 0.41^{\mathrm{abc}}$ & $83.70 \pm 2.38^{\mathrm{b}}$ & $1299.39 \pm 9.31^{\mathrm{abc}}$ \\
\hline & 15 & $29.30 \pm 0.54^{\text {cdef }}$ & $1.94 \pm 0.02^{\mathrm{cd}}$ & $6.90 \pm 1.46^{\text {abcd }}$ & $7.38 \pm 0.53^{a}$ & $1.81 \pm 0.55^{\text {cde }}$ & $83.78 \pm 1.82^{b}$ & $1281.15 \pm 2.35^{\mathrm{ab}}$ \\
\hline & 20 & $28.98 \pm 1.61^{\text {bcdef }}$ & $2.32 \pm 0.02^{\mathrm{e}}$ & $5.43 \pm 1.26^{\mathrm{a}}$ & $8.66 \pm 1.31^{\mathrm{ab}}$ & $1.96 \pm 0.51^{\text {cde }}$ & $83.59 \pm 0.42^{b}$ & $1302.55 \pm 48.27^{\mathrm{bc}}$ \\
\hline \multirow{4}{*}{ WF-PPR } & 5 & $27.09 \pm 0.59^{\mathrm{abc}}$ & $1.83 \pm 0.16 b^{c}$ & $5.85 \pm 1.59^{\mathrm{a}}$ & $8.52 \pm 1.53^{\mathrm{ab}}$ & $0.77 \pm 0.35^{\mathrm{ab}}$ & $83.80 \pm 1.52^{b}$ & $1333.72 \pm 34.30^{\text {cde }}$ \\
\hline & 10 & $27.30 \pm 1.07^{\mathrm{abcd}}$ & $1.94 \pm 0.15^{\mathrm{cd}}$ & $6.46 \pm 1.02^{\mathrm{abc}}$ & $8.90 \pm 0.68^{\mathrm{ab}}$ & $1.39 \pm 0.57^{\mathrm{abc}}$ & $82.70 \pm 0.48 d^{b}$ & $1337.88 \pm 20.83^{\text {cde }}$ \\
\hline & 15 & $28.17 \pm 0.87^{\text {abcde }}$ & $1.97 \pm 0.14^{\mathrm{cd}}$ & $7.27 \pm 2.42^{\mathrm{abcd}}$ & $7.47 \pm 0.53^{\mathrm{a}}$ & $2.00 \pm 0.52^{\text {cde }}$ & $83.29 \pm 3.02^{b}$ & $1303.84 \pm 23.88^{\mathrm{bc}}$ \\
\hline & 20 & $30.88 \pm 0.73^{f}$ & $2.43 \pm 0.52^{\mathrm{e}}$ & $5.65 \pm 0.59^{\mathrm{a}}$ & $7.73 \pm 1.23^{\mathrm{a}}$ & $2.83 \pm 0.89^{f}$ & $84.19 \pm 1.63^{\mathrm{b}}$ & $1257.90 \pm 18.43^{\mathrm{a}}$ \\
\hline
\end{tabular}

${ }^{* *}$ Cupcakes were processed with different concentration from potato residues: see material and methods. ${ }^{*}$ Data was calculated as percentages (\%). "All of data were calculated on dry weight basis. ${ }^{a, b, c}$ : Means with the same letter in the same column are not significantly different $(p>0.05)$. 

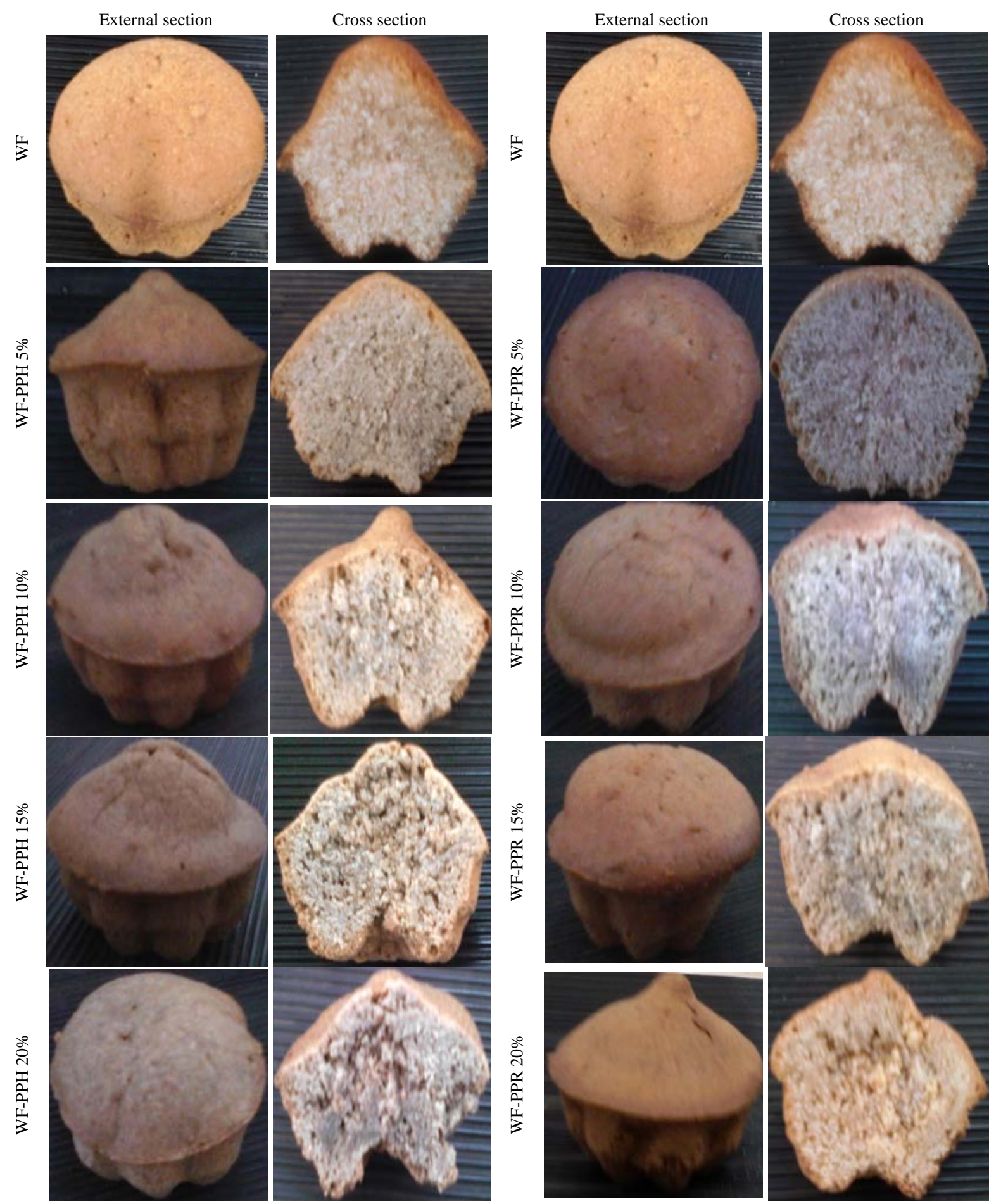

Figure 3. The effect of WF substitution by potato peels residue [Hermus (WF-PPH) and Russet (WF-PPR)] at $5 \%$ - $20 \%$ on whole cupcake morphological features as shown in external and cross sections. Cupcakes were backed at $180^{\circ} \mathrm{C} \pm 5^{\circ} \mathrm{C}$ for 30 - 35 min.

\subsection{Total Phenolic Compounds and Antioxidant Activity of Different WF Cupcakes Substituted with Potato Peels Residue}

The TPC and relative AOA of all formulated cupcakes were investigated; data is presented in Table 6. No 
Table 6. Total phenolic compounds and relative antioxidant activity of WF and different substituted WF cupcakes with potato peels residues.

\begin{tabular}{cccc}
\hline Cupcake formulas & Substitution level (\%) & TPC $^{*}$ & AOA $^{* *}$ \\
\hline WF & 0 & $1.43 \pm 0.18^{\mathrm{abc}}$ & $0.55 \pm 0.39^{\mathrm{ab}}$ \\
\hline WF-PPH & 5 & $1.78 \pm 0.05^{\mathrm{cdef}}$ & $1.01 \pm 0.23^{\mathrm{abc}}$ \\
& 10 & $1.43 \pm 0.10^{\mathrm{abc}} \pm 0.36^{\mathrm{bcd}}$ \\
& 15 & $1.51 \pm 0.14^{\mathrm{bcd}}$ & $2.55 \pm 0.42^{\mathrm{g}}$ \\
\hline WF-PPR & 20 & $1.98 \pm 0.27^{\mathrm{efg}}$ & $2.40 \pm 0.23^{\mathrm{fg}}$ \\
\hline & 5 & $1.41 \pm 0.21^{\mathrm{abc}}$ & $0.37 \pm 0.42^{\mathrm{a}}$ \\
& 10 & $1.64 \pm 0.12^{\mathrm{bcde}}$ & $1.81 \pm 0.03^{\mathrm{defg}}$ \\
& 15 & $2.32 \pm 0.30^{\mathrm{g}}$ & $2.28 \pm 1.02^{\mathrm{efg}}$ \\
\hline
\end{tabular}

'Cakes were processed with different concentration from potato residues: see material and methods. ${ }^{*}$ Total phenolic compound were calculated as mg $\mathrm{GAE} \mathrm{g}^{-1} \mathrm{dw},{ }^{* *}$ Antioxidant activity was calculated as $\mu$ mol TE $\mathrm{g}^{-1} \mathrm{dw}$. ${ }^{\mathrm{a}, \mathrm{b}, \mathrm{c}}$ : Means with the same letter in the same column are not significantly different $(p>0.05)$.

significant differences $(p>0.05)$ in TPC were observed between WF and both PP cupcakes at $5 \%-10 \%$. In contrast, significant differences $(p<0.05$ ) were found between WF and both PP cupcakes at $15 \%$ and $20 \%$; except WF-PPH 15\%. Arguably, increasing of substitution level caused increasing in TPC especially from PPR. Afterwards, WF-PPR 15\% cupcake recorded the highest TPC content; nevertheless the WF-PPR 5\% cupcake was the lowest TPC content to be 2.32 and $1.41 \mathrm{mg} \mathrm{GAE} \mathrm{g}^{-1} \mathrm{dw}$, respectively. Not only, WF-PPR cupcakes at higher concentrations listed the highest TPC content, but also they recorded the highest AOA compared with other cupcakes. Furthermore, the WF-PPR 20\% cupcake recorded higher AOA than different cupcakes followed by WF-PPH 15\% cupcake to be 3.44 and $2.55 \mu \mathrm{mol} \mathrm{TE} \mathrm{g}{ }^{-1} \mathrm{dw}$, respectively. Surely, significant differences ( $p<$ 0.05 ) were found between WF cupcake and all substitution levels of both PP residue at $15 \%$ and $20 \%$. For this reason, the increasing of PP residue concentration increased AOA accordingly. The WF and PPH 5\% cupcakes were lower in AOA than all cupcakes. This may be due to that increasing of phytochemicals as a result of increasing of PP residue levels. The AOA could enhance the bakery products shelf-life stability and retain the oil oxidation especially in cake products using the food processing residues. These results are in agreement with [4] [26] [46].

\subsection{Physical Properties of Different WF Cupcakes Substituted with Potato Peels Residue}

The physical properties of WF cupcakes substituted with potato peels residue at 5\% - 20\% including weight (g), volume $\left(\mathrm{cm}^{3}\right)$ and specific volume $\left(\mathrm{cm}^{3} \cdot \mathrm{g}^{-1}\right)$ were determined; data was illustrated in Table 7 . Clearly, increasing of PP substitution level increased the weight property. As for volume and specific volume characteristics, significant differences $(p<0.05)$ were exhibited between WF and all cupcakes. Furthermore, the WF cupcake demonstrated the highest volume and specific volume to be $108.00 \mathrm{~cm}^{3}$ and $2.62 \mathrm{~cm}^{3} \cdot \mathrm{g}^{-1}$, respectively. Also, WF-PPR 5\% cupcake was followed the WF cupcakes in specific volume, while WF-PPR 5\% cupcake was followed the WF cupcake in volume. Significant differences $(p<0.05)$ in physical properties were found between WF and PP cupcakes when incorporated 5\%, 10\%, 15\% and 20\%. Accordingly, increasing the PP residue level could bind more water which increasing the weight. In contrary, increasing the PP residue level was decreased the volume and specific volume being affecting the gluten net with low strength and gas retention. These results are agreements with some previous studies [24] [28] [44] [45] [47].

\subsection{Determination of Some Microbiological and Chemical Attributes of Different WF Cupcakes Substituted with Potato Peels Residue during Storage}

\subsubsection{Microbiological Attributes}

The microbiological attributes such as TBC, CG and Y \& M of the different WF cupcakes substituted with PP 
residue during storage at zero, fifth and eighth day at ambient temperature were examined; data was shown in Table 8. The TBC and Y \& M increased as storage period was extended significantly $(p<0.05)$. Usually, substituted cupcakes with both PP residues were higher in TBC and Y \& M than WF cupcake during storage period. WF-PPR 20\% cupcake recorded the highest TBC at zero time. WF-PPH 15\% and WF-PPH 20\% cupcakes were higher in TBC than all cupcakes after five and eight days, respectively. On the other hand, WF cupcake was the lowest in Y \& M especially during storage periods. However, CG wasn't detected in all cupcakes during storage period.

\subsubsection{TBA Determination}

The oxidative rancidity level is an important indicator for quality of stored foods. To assess the development of rancidity in cupcakes, the TBA was determined during storage time; data is summarized in Table 9. TBA was

Table 7. Physical properties of WF and different substituted WF cupcakes with potato peels residues.

\begin{tabular}{|c|c|c|c|c|}
\hline \multirow{2}{*}{ Cupcake formulas" } & \multirow{2}{*}{ Substitution level (\%) } & \multicolumn{3}{|c|}{ Properties } \\
\hline & & Weight (g) & Volume $\left(\mathrm{cm}^{3}\right)$ & Specific volume $\left(\mathrm{cm}^{3} \cdot \mathrm{g}^{-1}\right)$ \\
\hline WF & 0 & $41.29 \pm 0.47^{\mathrm{a}}$ & $108.00 \pm 1.00^{\mathrm{e}}$ & $2.62 \pm 0.01^{\mathrm{d}}$ \\
\hline \multirow{4}{*}{ WF-PPH } & 5 & $41.57 \pm 0.82^{\mathrm{b}}$ & $93.83 \pm 4.48^{\mathrm{cd}}$ & $2.26 \pm 0.15^{\mathrm{c}}$ \\
\hline & 10 & $52.95 \pm 1.27^{\mathrm{d}}$ & $94.00 \pm 2.00^{\mathrm{cd}}$ & $1.78 \pm 0.01^{\mathrm{ab}}$ \\
\hline & 15 & $53.34 \pm 1.25^{\mathrm{d}}$ & $87.00 \pm 2.00^{\mathrm{ab}}$ & $1.63 \pm 0.07^{\mathrm{a}}$ \\
\hline & 20 & $53.02 \pm 3.12^{\mathrm{d}}$ & $94.00 \pm 5.00^{\mathrm{cd}}$ & $1.78 \pm 0.20^{\mathrm{ab}}$ \\
\hline \multirow{4}{*}{ WF-PPR } & 5 & $41.25 \pm 0.93^{\mathrm{a}}$ & $94.83 \pm 2.02^{\mathrm{cd}}$ & $2.30 \pm 0.09^{c}$ \\
\hline & 10 & $51.64 \pm 0.80^{\mathrm{cd}}$ & $91.67 \pm 2.08^{\mathrm{abcd}}$ & $1.78 \pm 0.03^{\mathrm{ab}}$ \\
\hline & 15 & $52.23 \pm 0.98^{\mathrm{d}}$ & $86.00 \pm 2.65^{\mathrm{a}}$ & $1.65 \pm 0.02^{\mathrm{a}}$ \\
\hline & 20 & $53.30 \pm 2.54^{\mathrm{d}}$ & $90.67 \pm 4.51^{\mathrm{abc}}$ & $1.71 \pm 0.16^{\mathrm{a}}$ \\
\hline
\end{tabular}

"Cakes were processed with different substitution level from potato peels residue: see material and methods. ${ }^{\text {ab,c. }}$ : Means with the same letter in the same column are not significantly different $(p>0.05)$.

Table 8. Microbiological attributes of WF and different substituted WF cupcakes with potato peels residue during storage periods at ambient temperature.

\begin{tabular}{|c|c|c|c|c|c|c|c|}
\hline \multirow{3}{*}{ Cupcake formula" } & \multirow{3}{*}{$\begin{array}{c}\text { Substitution } \\
\text { level (\%) }\end{array}$} & \multicolumn{6}{|c|}{ Microbiological attributes*/storage period } \\
\hline & & \multicolumn{3}{|c|}{ TBC $\left[\log \mathrm{CFU} \mathrm{g}^{-1}\right]$} & \multicolumn{3}{|c|}{$\mathrm{Y} \& \mathrm{M}\left[\log \mathrm{CFU} \mathrm{g} \mathrm{g}^{-1}\right]$} \\
\hline & & 0 day & 5 days & 8 days & 0 day & 5 days & 8 days \\
\hline WF & 0 & $2.08 \pm 0.14^{\mathrm{Ab}}$ & $2.76 \pm 0.33^{\mathrm{Ba}}$ & $5.23 \pm 0.03^{\mathrm{Ca}}$ & nd & $1.54 \pm 0.26^{\mathrm{Aa}}$ & $3.71 \pm 0.35^{\mathrm{Ba}}$ \\
\hline \multirow{4}{*}{ WF-PPH } & 5 & $2.12 \pm 0.16^{\mathrm{Abc}}$ & $3.84 \pm 0.36^{\mathrm{Bc}}$ & $5.90 \pm 0.14^{\mathrm{Cb}}$ & nd & $1.57 \pm 0.10^{\mathrm{Aa}}$ & $4.03 \pm 0.05^{\mathrm{Bb}}$ \\
\hline & 10 & $2.17 \pm 0.11^{\mathrm{Ac}}$ & $4.07 \pm 0.11^{\text {Bde }}$ & $5.99 \pm 0.07^{\mathrm{Cbc}}$ & nd & $1.79 \pm 0.16^{\mathrm{Ac}}$ & $4.72 \pm 0.19^{\mathrm{Bd}}$ \\
\hline & 15 & $2.18 \pm 0.07^{\mathrm{Ac}}$ & $4.14 \pm 0.02^{\mathrm{Be}}$ & $6.09 \pm 0.06^{\mathrm{Cc}}$ & nd & $1.83 \pm 0.27^{\mathrm{Ad}}$ & $5.09 \pm 0.21^{\mathrm{Bf}}$ \\
\hline & 20 & $2.07 \pm 0.11^{\mathrm{Ab}}$ & $3.93 \pm 0.04^{\mathrm{Bc}}$ & $6.30 \pm 0.03^{\mathrm{Cd}}$ & nd & $1.82 \pm 0.07^{\mathrm{Ad}}$ & $4.98 \pm 0.41^{\mathrm{Be}}$ \\
\hline \multirow{4}{*}{ WF-PPR } & 5 & $1.95 \pm 0.12^{\mathrm{Aa}}$ & $3.54 \pm 0.21^{\mathrm{Bb}}$ & $5.92 \pm 0.14^{\mathrm{Cbc}}$ & nd & $1.62 \pm 0.22^{\mathrm{Ab}}$ & $5.33 \pm 0.05^{\mathrm{Bh}}$ \\
\hline & 10 & $2.06 \pm 0.09^{\mathrm{Ab}}$ & $3.94 \pm 0.09^{\mathrm{Bcd}}$ & $6.00 \pm 0.06^{\mathrm{Cc}}$ & nd & $1.86 \pm 0.03^{\text {Ade }}$ & $4.32 \pm 0.14^{\mathrm{Bc}}$ \\
\hline & 15 & $2.17 \pm 0.14^{\mathrm{Ac}}$ & $4.04 \pm 0.02^{\mathrm{Bd}}$ & $6.24 \pm 0.14^{\mathrm{Cd}}$ & nd & $1.96 \pm 0.11^{\mathrm{Ae}}$ & $5.04 \pm 0.06^{\mathrm{Bg}}$ \\
\hline & 20 & $2.22 \pm 0.08^{\mathrm{Ac}}$ & $3.48 \pm 0.14^{\mathrm{Bb}}$ & $6.28 \pm 0.03^{\mathrm{Cd}}$ & nd & $1.87 \pm 0.09^{\mathrm{Ad}}$ & $5.17 \pm 0.18^{\mathrm{Bg}}$ \\
\hline
\end{tabular}

"Cupcakes were processed with different concentration from potato residues: see material and methods, ${ }^{\text {A,B,C}}$ : Means with the same letter in the same row are not significantly different $(p>0.05) .{ }^{\mathrm{a}, \mathrm{b}, \mathrm{c}}$ : Means with the same letter in the same column are not significantly different $(p>0.05)$, ${ }^{\text {nd}}$ : Not detected. 
Table 9. Monitoring of TBA and staling of WF and different substituted WF cupcakes with potato peels residues during storage periods at ambient temperature.

\begin{tabular}{|c|c|c|c|c|c|c|c|}
\hline \multirow{3}{*}{$\begin{array}{l}\text { Cupcake } \\
\text { formula" }\end{array}$} & \multirow{3}{*}{$\begin{array}{l}\text { Substitution ratio } \\
\text { (\%) }\end{array}$} & \multicolumn{6}{|c|}{ Quality indicators/storage period } \\
\hline & & \multicolumn{3}{|c|}{ TBA [malonaldehyde $\mathrm{kg}^{-1}$ ] } & \multicolumn{3}{|c|}{ Staling [\%] } \\
\hline & & 0 day & 5 days & 8 days & 0 days & 5 days & 8 days \\
\hline WF & 0 & $0.166 \pm 0.00^{\mathrm{Ac}}$ & $0.260 \pm 0.03^{\mathrm{Bffg}}$ & $0.330 \pm 0.03^{\mathrm{Cc}}$ & $329 \pm 7.07^{\mathrm{Cab}}$ & $280 \pm 2.83^{\mathrm{Ba}}$ & $212 \pm 8.49^{\text {Аа }}$ \\
\hline \multirow{4}{*}{ WF-PPH } & 5 & $0.164 \pm 0.02^{\mathrm{Ac}}$ & $0.182 \pm 0.03^{\mathrm{Bab}}$ & $0.333 \pm 0.03^{\mathrm{Cc}}$ & $361 \pm 12.73^{\mathrm{Bab}}$ & $355 \pm 7.07^{\mathrm{Bbc}}$ & $330 \pm 14.14^{\mathrm{Abc}}$ \\
\hline & 10 & $0.182 \pm 0.04^{\mathrm{Ad}}$ & $0.252 \pm 0.03^{\mathrm{Be}}$ & $0.361 \pm 0.04^{\mathrm{Cd}}$ & $381 \pm 4.24^{\mathrm{Cb}}$ & $346 \pm 8.49^{\mathrm{Bbc}}$ & $307 \pm 12.73^{\mathrm{Abc}}$ \\
\hline & 15 & $0.179 \pm 0.03^{\mathrm{Ad}}$ & $0.208 \pm 0.06^{\mathrm{Bbc}}$ & $0.354 \pm 0.04^{\mathrm{Cd}}$ & $471 \pm 21.21^{\mathrm{Cc}}$ & $436 \pm 14.14^{\mathrm{Bcd}}$ & $385 \pm 35.36^{\mathrm{Ac}}$ \\
\hline & 20 & $0.182 \pm 0.03^{\mathrm{Ad}}$ & $0.213 \pm 0.03^{\mathrm{Bc}}$ & $0.356 \pm 0.01^{\mathrm{Cd}}$ & $499 \pm 15.56^{\mathrm{Cd}}$ & $433 \pm 7.07^{\mathrm{Bcd}}$ & $407 \pm 4.24^{\mathrm{Ad}}$ \\
\hline \multirow{4}{*}{ WF-PPR } & 5 & $0.169 \pm 0.03^{\text {Acd }}$ & $0.221 \pm 0.02^{\mathrm{Bcd}}$ & $0.286 \pm 0.07^{\mathrm{Cb}}$ & $397 \pm 35.36^{\mathrm{Cbc}}$ & $377 \pm 4.24^{\mathrm{Bbc}}$ & $360 \pm 2.83^{\text {Adcd }}$ \\
\hline & 10 & $0.156 \pm 0.05^{\mathrm{Abc}}$ & $0.203 \pm 0.06^{\mathrm{Bbc}}$ & $0.255 \pm 0.04^{\mathrm{Ca}}$ & $442 \pm 39.60^{\mathrm{Cc}}$ & $378 \pm 22.63^{\mathrm{Bbc}}$ & $342 \pm 14.14^{\mathrm{Abc}}$ \\
\hline & 15 & $0.135 \pm 0.03^{\mathrm{Aa}}$ & $0.229 \pm 0.03^{\mathrm{Bcd}}$ & $0.268 \pm 0.04^{\mathrm{Cab}}$ & $466 \pm 14.14^{\mathrm{Ccd}}$ & $408 \pm 16.97^{\mathrm{Bc}}$ & $398 \pm 11.31^{\text {Acd }}$ \\
\hline & 20 & $0.169 \pm 0.01^{\mathrm{Acd}}$ & $0.226 \pm 0.05^{\mathrm{Bcd}}$ & $0.273 \pm 0.05^{\mathrm{Cb}}$ & $503 \pm 9.90^{\mathrm{Cd}}$ & $481 \pm 9.90^{\mathrm{Bd}}$ & $391 \pm 12.73^{\text {Acd }}$ \\
\hline
\end{tabular}

"Cakes were processed with different concentration from potato residues: see material and methods. ${ }^{\text {A,B,C}}$ : Means with the same letter in the same row are not significantly different $(p>0.05) .{ }^{a, b, c}$ : Means with the same letter in the same column are not significantly different $(p>0.05)$.

increased during storage period in all WF and PP cupcakes significantly. The deterioration as mg malonaldehyde $\mathrm{kg}^{-1}$ was higher in PPH than PPR cupcakes as observed after 8 days, significantly. The TBA indicated that WF-PPR cupcakes were the most stable during storage period. However, substitution of WF by $10 \%-15 \%$ PP residue may reduce the oil rancidity and reduce the TBA, while increasing PP residues more than $15 \%$ or $20 \%$ may cause releasing of oil out from the gluten net thereby oxidized quickly by outer oxidation factors. Sharif $e t$ al. [48] evident that the using of rice bran oil decreased the TBA in cookies during storage periods. Also, Hafez [1] suggested that marjoram could be used to extend the shelf-life stability of cakes by decreasing the TBA during storage. However, Al-Sayed and Ahmed [24] used watermelon rinds and sharlyn melon peels extracts to retard oil oxidation in cake.

\subsubsection{Staling Determination}

Changing in staling of different baked cupcake during storage at ambient temperature was determined; results are shown in Table 9. The staling values of different cupcake formula were gradually reduced significantly ( $p<$ 0.05) during storage periods. The lower reduction in staling values equal a high freshness was achieved in WF and both PP 5\% cupcakes. Obtained results noticed that the substituting of $15 \%$ and $20 \%$ flour by PPH or PPR recorded the highest staling values at the end of storage. Otherwise WF cupcake recorded the lowest staling at the end of storage to be $212 \%$. These results were asserted that WF cupcake was exhibited the best staling result, followed by substituted cupcakes with PP at $5 \%$ or $10 \%$. However, the best of our knowledge, Al-Sayed and Ahmed [24] outlined that the using of watermelon and sharlyn lemon peel powders retard significantly staling of cakes compared with control cakes.

\section{Conclusion}

A successful and innovative formulation of cupcake production with both PP residues was developed. The WF-PP cupcakes at different substituted levels recorded lower energy value than WF cupcakes. The substitutions of WF with both PP at 5\% and 10\% did not influence the thermo-mechanical and rheological properties drastically. Cupcake formulas with partial substitution of flour with 5\% - 15\% PPH or PPR had more natural phenolics as compared with WF cupcakes. The PPH and PPR are providing AOA to increase the shelf-life stability, reduce oil rancidity and improve staling. Substitution of WF by $5 \%-15 \%$ is recommended to produce an acceptable cupcake by consumers. Adding more than $15 \%$ PP residue couldn't be applicable regarding its negative effects on cupcake characteristics. However, it could be recommended that using of PPH and PPR should be 
encouraged the food industries to utilize local raw materials economically into cupcake to produce low calories as functional food products.

\section{References}

[1] Hafez, A.A. (2012) Physico-Chemical and Sensory Properties of Cakes Supplemented with Different Concentration of Marjoram. Australian Journal of Basic and Applied Sciences, 6, 463-470.

[2] Hussain, S. and Al-Oulabi, R. (2009) Studying the Possibility of Preparing an Egg-Free or Egg-Less Cake. International Journal of Engineering \& Technology, 1, 324-329. http://dx.doi.org/10.7763/IJET.2009.V1.65

[3] Zhang, Y., Song, Y., Hu, X., Liao, X., Ni, Y. and Li, Q. (2012) Effects of Sugars in Batter Formula and Baking Conditions on 5-Hydroxymethylfurfural and Furfural Formation in Sponge Cake Models. Food Research International, 49, 439-445. http://dx.doi.org/10.1016/j.foodres.2012.07.012

[4] Ahmed, A.R. (2014) Influence of Chemical Properties of Wheat-Lupine Flour Blends on Cake Quality. American Journal of Food Science and Technology, 2, 67-75. http://dx.doi.org/10.12691/ajfst-2-2-4

[5] Rodríguez, R., Jimenez, A., Fernández-Bolaños, J., Guillén, R. and Heredia, A. (2006) Dietary Fibre from Vegetable Products as Source of Functional Ingredients. Trends in Food Science and Technology, 17, 3-15. http://dx.doi.org/10.1016/j.tifs.2005.10.002

[6] Leo, L., Leone, A., Longo, C., Lombardi, D.A., Raimo, F. and Zacheo, G. (2008) Antioxidant Compounds and Antioxidant Activity in "Early Potatoes". Journal of Agricultural and Food Chemistry, 56, 4154-4163. http://dx.doi.org/10.1021/jf073322w

[7] FAO (2013) Production of Potato. http://faostat3.fao.org/browse/Q/QC/E

[8] Habeebullah, K., Nielsen, N. and Jacobsen, C. (2010) Antioxidant Activity of Potato Peel Extracts in a Fish-Rapeseed Oil Mixture and in Oil-in-Water Emulsions. Journal of the American Oil Chemists' Society, 87, 1319-1332. http://dx.doi.org/10.1007/s11746-010-1611-0

[9] Amado, I.R., Franco, D., Sánchez, M., Zapata, C. and Vázquez, J.A. (2014) Optimization of Antioxidant Extraction from (Solanum tuberosum) Potato Peel Waste by Surface Response Methodology. Food Chemistry, 165, 290-299. http://dx.doi.org/10.1016/j.foodchem.2014.05.103

[10] Al-Weshahy, A., El-Nokety, M., Bakhete, M. and Rao, V. (2013) Effect of Storage on Antioxidant Activity of FreezeDried Potato Peels. Food Research International, 50, 507-512. http://dx.doi.org/10.1016/j.foodres.2010.12.014

[11] Mohagheghi, S.A., Poorazarang, H., Hematyar, N. and Elhamirad, A. (2012) Phenolics in Potato Peels: Extraction and Utilization as Natural Antioxidants. World Applied Sciences Journal, 18, 191-195.

[12] Mohdaly, A.A.A., Sarhan, M.A., Smetanska, I. and Mahmoud, A. (2010) Antioxidant Properties of Various Solvent Extracts of Potato Peel, Sugar Beet Pulp and Sesame Cake. Journal of the Science of Food and Agriculture, 90, 218226. http://dx.doi.org/10.1002/jsfa.3796

[13] Li, K.H., Eung-Jun, P., Hoi-Seon, L., Dong-Man, K., Stephen, L.L. and Hak-Tae, L. (2006) Evaluation of Potato Varieties with High Antioxidant Activities by Measuring Phenolic Acids in Different Tuber Parts. Horticulture, Environment, and Biotechnology, 47, 126-131.

[14] Al-Weshahy, A. and Venket Rao, A. (2009) Isolation and Characterization of Functional Components from Peel Samples of Six Potatoes Varieties Growing in Ontario. Food Research International, 42, 1062-1066. http://dx.doi.org/10.1016/j.foodres.2009.05.011

[15] Wu, Z., Xu, H., Ma, Q., Cao, Y., Ma, J. and Ma, C. (2012) Isolation, Identification and Quantification of Unsaturated Fatty Acids, Amides, Phenolic Compounds and Glycoalkaloids from Potato Peel. Food Chemistry, 135, 2425-2429. http://dx.doi.org/10.1016/j.foodchem.2012.07.019

[16] Albishi, T., John, J.A., Al-Khalifa, A.S. and Shahidi, F. (2013) Phenolic Content and Antioxidant Activities of Selected Potato Varieties and Their Processing By-Products. Journal of Functional Foods, 5, 590-600. http://dx.doi.org/10.1016/j.jff.2012.11.019

[17] Dhingra, D., Michael, M. and Rajput, H. (2012) Physico-Chemical Characteristics of Dietary Fibre from Potato Peel and Its Effect on Organoleptic Characteristics of Biscuits. Journal of Agricultural Engineering, 49, 25-32.

[18] Slavin, J.L. (2005) Dietary Fiber and Body Weight. Nutrition, 21, 411-418. http://dx.doi.org/10.1016/j.nut.2004.08.018

[19] Nomura, A., Hankin, J., Henderson, B., Wilkens, L., Murphy, S., Pike, M., Le Marchand, L., Stram, D., Monroe, K. and Kolonel, L. (2007) Dietary Fiber and Colorectal Cancer Risk: The Multiethnic Cohort Study. Cancer Causes \& Control, 18, 753-764. http://dx.doi.org/10.1007/s10552-007-9018-4

[20] Roth, J. and Mobarhan, S. (2001) Preventive Role of Dietary Fiber in Gastric Cardia Cancers. Nutrition Reviews, 59, 372-374. 
[21] King, D.E. (2005) Dietary Fiber, Inflammation, and Cardiovascular Disease. Molecular Nutrition \& Food Research, 49, 594-600. http://dx.doi.org/10.1002/mnfr.200400112

[22] Gómez, M., Moraleja, A., Oliete, B., Ruiz, E. and Caballero, P.A. (2010) Effect of Fibre Size on the Quality of FibreEnriched Layer Cakes. LWT-Food Science and Technology, 43, 33-38. http://dx.doi.org/10.1016/j.lwt.2009.06.026

[23] Santos, A.C., Yassunaka, N.N., Ruiz, S.P., Schneider, V.V.A., Visentainer, J.V. and Madrona, G.S. (2014) Sensory and Physicochemical Study of Carrot Leaf Sponge Cake. Revista Brasileira de Pesquisa em Alimentos, 4, 41-46. http://dx.doi.org/10.14685/rebrapa.v4i2.121

[24] Al-Sayed, H. and Ahmed, A.R. (2013) Utilization of Watermelon Rinds and Sharlyn Melon Peels as a Natural Source of Dietary Fiber and Antioxidants in Cake. Annals of Agricultural Sciences, 58, 83-95. http://dx.doi.org/10.1016/j.aoas.2013.01.012

[25] Kaack, K. and Pedersen, L. (2005) Low Energy Chocolate Cake with Potato Pulp and Yellow Pea Hulls. European Food Research and Technology, 221, 367-375. http://dx.doi.org/10.1007/s00217-005-1181-9

[26] Moraes, É.A., Dantas, M., Morais, D., Silva, C., Castro, F., Martino, H. and Ribeiro, S. (2010) Sensory Evaluation and Nutritional Value of Cakes Prepared with Whole Flaxseed Flour. Food Science and Technology (Campinas), 30, 974979.

[27] Masoodi, F.A., Sharma, B. and Chauhan, G.S. (2002) Use of Apple Pomace as a Source of Dietary Fiber in Cakes. Plant Foods for Human Nutrition, 57, 121-128. http://dx.doi.org/10.1023/A:1015264032164

[28] Sudha, M.L., Baskaran, V. and Leelavathi, K. (2007) Apple Pomace as a Source of Dietary Fiber and Polyphenols and Its Effect on the Rheological Characteristics and Cake Making. Food Chemistry, 104, 686-692. http://dx.doi.org/10.1016/j.foodchem.2006.12.016

[29] AACC (2002) Approved Methods of the American Association of Cereal Chemists. American Association of Cereal Chemists, St. Paul.

[30] Heywood, A.A., Myers, D.J., Bailey, T.B. and Johnson, L.A. (2002) Functional Properties of Low-Fat Soy Flour Produced by an Extrusion-Expelling System. Journal of the American Oil Chemists' Society, 79, 1249-1253. http://dx.doi.org/10.1007/s11746-002-0635-y

[31] Kuniak, L. and Marchessault, R.H. (1972) Study of the Crosslinking Reaction between Epichlorohydrin and Starch. Starch-Stärke, 24, 110-116. http://dx.doi.org/10.1002/star.19720240404

[32] AACC (2000) Approved Methods of the American Association of Cereal Chemists. American Association of Cereal Chemists, St. Paul.

[33] FAO (2003) Food Energy—Methods of Analysis and Conversion Factors. Food and Nutrition Paper, Rome, 77.

[34] Lee, S.C., Kim, J.H., Jeong, S.M., Kim, D.R., Ha, J.U., Nam, K.C. and Ahn, D.U. (2003) Effect of Far-Infrared Radiation on the Antioxidant Activity of Rice Hulls. Journal of Agricultural and Food Chemistry, 51, 4400-4403. http://dx.doi.org/10.1021/jf0300285

[35] AOCS (2006) Official Methods and Recommended Practices of the American Oil Chemist’s Society. Champaign.

[36] Dubat, A. (2010) A New AACC International Approved Method to Measure Rheological Properties of a Dough Sample. Cereal Foods World, 55, 150-153.

[37] Steel, R., Torrie, J. and Dickey, D. (1996) Principles and Procedures of Statistics: A Biometrical Approach. 3 Sub Edition, McGraw-Hill, New York.

[38] Traynham, T.L., Myers, D.J., Carriquiry, A.L. and Johnson, L.A. (2007) Evaluation of Water-Holding Capacity for Wheat-Soy Flour Blends. Journal of the American Oil Chemists' Society, 84, 151-155. http://dx.doi.org/10.1007/s11746-006-1018-0

[39] El-Safy, F.S., Salem, R.H. and Abd El-Ghany, M. (2012) Chemical and Nutritional Evaluation of Different Seed Flours as Novel Sources of Protein. World Journal of Dairy \& Food Sciences, 7, 59-65.

[40] Kahraman, K., Sakıyan, O., Ozturk, S., Koksel, H., Sumnu, G. and Dubat, A. (2008) Utilization of Mixolab ${ }^{\circledR}$ to Predict the Suitability of Flours in Terms of Cake Quality. European Food Research and Technology, 227, 565-570. http://dx.doi.org/10.1007/s00217-007-0757-y

[41] Purwandari, U., Hidayati, D., Tamam, B. and Arifin, S. (2014) Gluten-Free Noodle Made from Gathotan (an Indonesian Fungal Fermented Cassava) Flour: Cooking Quality, Textural, and Sensory Properties. Food Research Journal, 21, 1951-1956.

[42] Torbica, A., Hadnađev, M. and Dapčević, T. (2010) Rheological, Textural and Sensory Properties of Gluten-Free Bread Formulations Based on Rice and Buckwheat Flour. Food Hydrocolloids, 24, 626-632. http://dx.doi.org/10.1016/j.foodhyd.2010.03.004

[43] Cho, Y.J., Bae, I.Y., Inglett, G.E. and Lee, S. (2014) Utilization of Tartary Buckwheat Bran as a Source of Rutin and Its Effect on the Rheological and Antioxidant Properties of Wheat-Based Products. Industrial Crops and Products, 61, 
211-216. http://dx.doi.org/10.1016/j.indcrop.2014.07.003

[44] Kim, J.H., Lee, H.J., Lee, H., Lim, E., Imm, J.Y. and Suh, H.J. (2012) Physical and Sensory Characteristics of FibreEnriched Sponge Cakes Made with Opuntia humifusa. LWT-Food Science and Technology, 47, 478-484. http://dx.doi.org/10.1016/j.lwt.2012.02.011

[45] Gularte, M.A., de la Hera, E., Gómez, M. and Rosell, C.M. (2012) Effect of Different Fibers on Batter and Gluten-Free Layer Cake Properties. LWT-Food Science and Technology, 48, 209-214. http://dx.doi.org/10.1016/j.lwt.2012.03.015

[46] Lu, T., Lee, C.Y., Mau, J. and Lin, S. (2010) Quality and Antioxidant Property of Green Tea Sponge Cake. Food Chemistry, 119, 1090-1095. http://dx.doi.org/10.1016/j.foodchem.2009.08.015

[47] Lebesi, D.M. and Tzia, C. (2012) Use of Endoxylanase Treated Cereal Brans for Development of Dietary Fiber Enriched Cakes. Innovative Food Science \& Emerging Technologies, 13, 207-214. http://dx.doi.org/10.1016/j.ifset.2011.08.001

[48] Sharif, K., Butt, M.S., Anjum, F.M. and Nasir, M. (2005) Improved Quality of Baked Products by Rice Bran Oil. Internet Journal of Food Safety, 5, 1-8. 
Scientific Research Publishing (SCIRP) is one of the largest Open Access journal publishers. It is currently publishing more than 200 open access, online, peer-reviewed journals covering a wide range of academic disciplines. SCIRP serves the worldwide academic communities and contributes to the progress and application of science with its publication.

Other selected journals from SCIRP are listed as below. Submit your manuscript to us via either submit@scirp.org or Online Submission Portal.
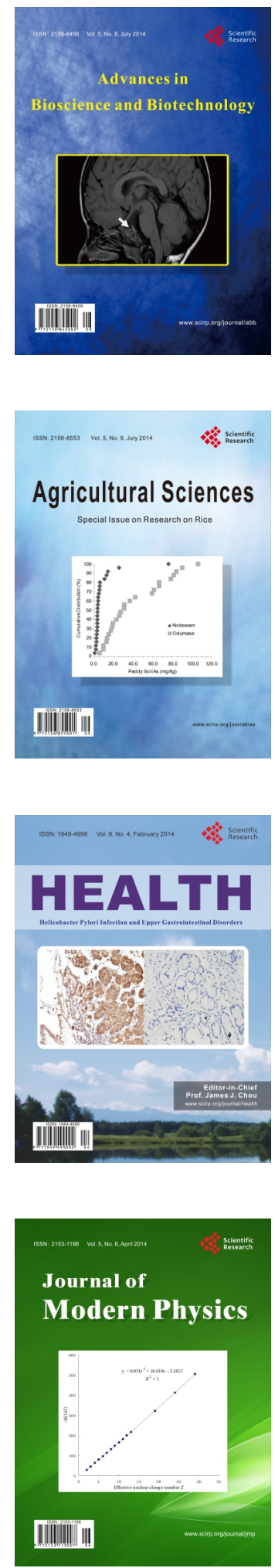
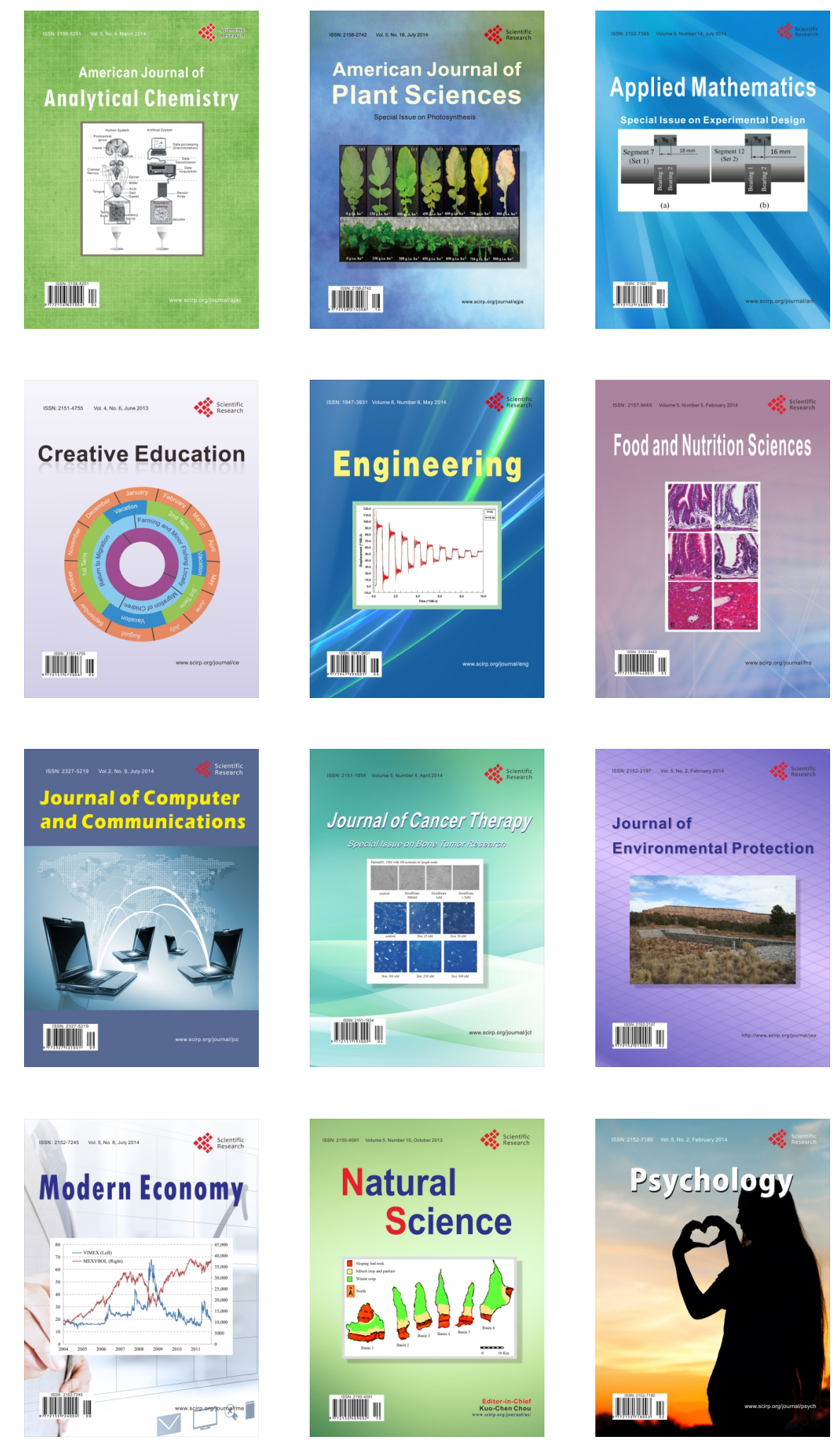